\title{
USING THE RESULTS OF A NATIONWIDE PHENOLOGICAL NETWORK TO EXAMINE THE IMPACT OF CHANGES IN PHENOLOGY OF PLANT SPECIES ON THE CONCENTRATION OF PLANT POLLEN IN THE AIR.
}

\author{
Katarzyna Jabłońska ${ }^{1}$, Piotr Rapiejko² \\ ${ }^{1}$ Centre for Poland's Climate Monitoring, Institute of Meteorology and Water Management, Podleśna 61 \\ Warsaw 01-673, Poland; e-mail: Katarzyna.Jatczak@imgw.pl \\ ${ }^{2}$ Department of Otolaryngology, Military Institute of Medicine, Szaserów 128, Warsaw 04-141, Poland
}

Received: 1.09 .2010

\section{Abstract}

The application of phenological data together with meteorological and pollen data in a comprehensive analysis gives an opportunity to draw conclusions on variability of the starting date of the pollen season and its dynamics in terms of meteorological factors.

It is quite important especially due to the fact that studies conducted all over Europe have proved that species phenology responds to climate warming trends. There has been observed a tendency to an earlier onset of spring flowering and leafing as well as the lengthening of the growing season. Although phenological network studies differ with regard to regions, species, events observed and applied methods, their data show a clear temperature-driven extension of the growing season by up to 2 weeks in the second half of the 20th century in mid- and high northern latitudes; for example, in Germany changes in timing of phenological spring events have been estimated at about -1.6 days / decade, while in Switzerland: -2.3 days / decade.

Despite interannual variability in flowering date, caused by specific meteorological conditions each year, long-time series of phenological data from the area of Poland have proved that hazel flowering occurred in the surroundings of Warsaw later in the 50's (third decade of March) than it is observed at the beginning of the 21st century (second decade of March).

There is a lack of such long time series of pollen data, but we can suspect that the hazel pollen season has changed similarly to the time pattern of its flowering.

Plants are very sensitive to weather conditions, therefore it is important to know as precisely as possible the impact of meteorological conditions on a plant's reactions. The determination of thermal thresholds for a specific plant's reactions may be beneficial for this purpose.

The estimated value of Positive Degree Days (PDD> 50), which caused the first Corylus flowers (F2 phenophase) to bloom in the study years, requires testing in future years to make the threshold values credible.

Key words: Corylus avellana, pollen season, growing season, phenology response, thermal thresholds

\section{INTRODUCTION}

Phenology is a study of the timing of recurring biological events in the animal and plant world. Flowering and leafing of plants in spring, fruit ripening, yellowing and leaf fall in autumn, etc. are all examples of such events.

The pattern of plant phenophases is an expression of thermal effects, changes in sunlight, and humidity conditions. The seasonality of vegetation is manifested also by the presence of pollen grains in the air. Pollen production and pollen concentration in the air have an annual periodicity. Daily values are also characterized by great instability (W a lanus, 1994). They depend on many different factors, such as the proportion of a given taxon in the vegetation, long-distance transport, and meteorological conditions ( $\mathrm{Pi} \mathrm{d} \mathrm{e} \mathrm{k,} \mathrm{2007).} \mathrm{The} \mathrm{relations} \mathrm{are} \mathrm{very} \mathrm{compli-}$ cated and not always do they give unequivocal results (S z c z e p a n e k, 1994). Sometimes individuals can be ready to flower but they cannot start flowering because it is too rainy or too humid, so pollen cannot be observed despite the fact that the flowering stage has been actually reached (S i lja mo, 2007). However, numerous analyses have demonstrated that pollen concentration is correlated significantly with different meteorological parameters, such as maximum air temperature, maximum wind speed, and humidity ( $\mathrm{Pide} \mathrm{k}$, 2007; P u c , 2007).

Aerobiological or phenological observations undoubtedly depend on meteorological conditions each year.

Thus, it is worth to analyze airborne pollen concentrations together with appropriate phenological data, taking into consideration the coincidence of flowering with the occurrence of allergenic pollen grains in the air (P u c, 2007). 
In turn, studies conducted all over Europe have proved that species phenology responds to climate warming trends. There has been observed an earlier onset of spring flowering and leafing as well as the lengthening of the growing season (Menzel et al. 2006). In Poland decreasing trends in Corylus avellana flowering have been estimated at about -2.4 days/decade ( $\mathrm{J}$ a t c $\mathrm{z}$ a k, 2007).

Similar tendencies have been noted in aerobiological research. Pollen seasons started earlier, they lasted longer, and allergenic pollen concentration in the air was higher (P a ł c z y ń s k i, 2004; N a i k, 2007). The number of days with high pollen concentration, important for allergy sufferers, was high (W e r y s z k o- Chmi e lew s ka and R a pi e j k o, 2007).

Thus, in this sense, changes in current weather conditions also pose many risks that can be adverse to human health by affecting species phenology and the time of pollen release. Changes in pollen season dates are associated with temporal shifts in the incidence of allergic symptoms and the deterioration of health in patients suffering from allergy. These are the results of the impact of genetic and environmental factors.

This kind of interdisciplinary research has proved the utility of phenological data. Throughout the world, phenological observations are a form of arousing public interest in science, especially among students and pupils. Phenological observations in Poland developed dynamically to the mid-twentieth century, mainly because of their practical importance in agriculture. In 2005 the Institute of Meteorology and Water Management launched the process of setting up a nationwide phenological network with a unified observation methodology and data file format.

The goal of this study was to use the results of the nationwide phenological network to examine the impact of changes in phenology of plant species on the concentration of plant pollen in the air. We tried to use temperature correlations with the phenological stages of flowering for a better interpretation of the results of aerobiological investigations during the study period.

\section{MATERIALS AND METHODS}

The analysis related to a species that participates in the development of pollen allergy symptoms in humans.

Daily Corylus avellana pollen concentrations in the years 2009 and 2010 in Warsaw were analyzed. Pollen data came from the Allergen Research Center and the Military Medical Institute. The start and end dates of the pollen season and days with maximum pollen concentration values were investigated. The pollen season was defined as the period when $95 \%$ of annual total pollen grains appeared in the air.
Phenology data were taken from the Institute of Meteorology and Water Management database that contains information on the generative development of plants, observed using Łukasiewicz's method in 7 stages: F1 - the appearance of the first flower or inflorescence buds; F2 - first bloom; F3 - beginning of full bloom ( $25 \%$ of flowers open); F4 - the first flowers shedding blossom; F5 - end of full bloom (75\% of flowers shedding blossom); F6 - the last flower buds; F7 - end of flowering. The observations were conducted at several-day intervals (every day - during F2 and $\mathrm{F} 3$ ). The data relating to $\mathrm{F} 2$ and $\mathrm{F} 3$ phenophases of $\mathrm{Co}$ rylus avellana in Warsaw in the years 2009 and 2010 were used in the analysis. We defined the start and end dates of the phenophases as well as their length. Dates of maximum pollen concentration during the phenophases F2 and F3 were compared in time.

Meteorological data - mean monthly temperature, average daily temperature from January to April in 2009 and 2010 in Warsaw - were used to estimate the influence of the warmth of winter and spring months on the dates of first bloom (F2) and pollen release every year.

Mean monthly temperatures were used to estimate monthly anomalies compared to 1971-2000 normal. By taking the sum of average daily temperatures above $0^{\circ} \mathrm{C}$ (from the 1 th of January to the day before the F2 phenophase date), we came up with a number called Positive Degree Days (PDD). We tried to check the specific PDD of which could cause the blossoming of the first flowers $(\mathrm{F} 2)$ in the study years.

\section{RESULTS}

The analyzed years had different thermal characteristics. In 2009 mean monthly anomalies of temperature were close to the long-term normal (January $0.5^{\circ} \mathrm{C}$, February $+0.6^{\circ} \mathrm{C}$; March $\left.+0.1^{\circ} \mathrm{C}\right)$, whereas April was a significantly warmer month $\left(+3.4^{\circ} \mathrm{C}\right)$ (Fig. 1.).

The following year we had the opposite situation. The 2010 winter season was very cold. The lowest negative anomaly appeared in January $\left(-5.8^{\circ} \mathrm{C}\right)$. Mean monthly anomalies in March and April exceeded $+1^{\circ} \mathrm{C}$ (Fig. 2.).

Thermal variations in 2009 and 2010 had a direct influence on the start of the growing period in these years. The dates of phenological phases, especially the date of first bloom (F2) but also of pollen release, depend on the warmth of winter and spring months. Therefore, the reaction of Corylus avellana was quite different in 2009 and 2010.

In 2009 the first flowers started to blossom (F2) on the 6th of March and after 6 days the flowers entered phenophase F3 (on March 12) (Figs. 3, 5). The Corylus avellana pollen season started on the 27 th of 

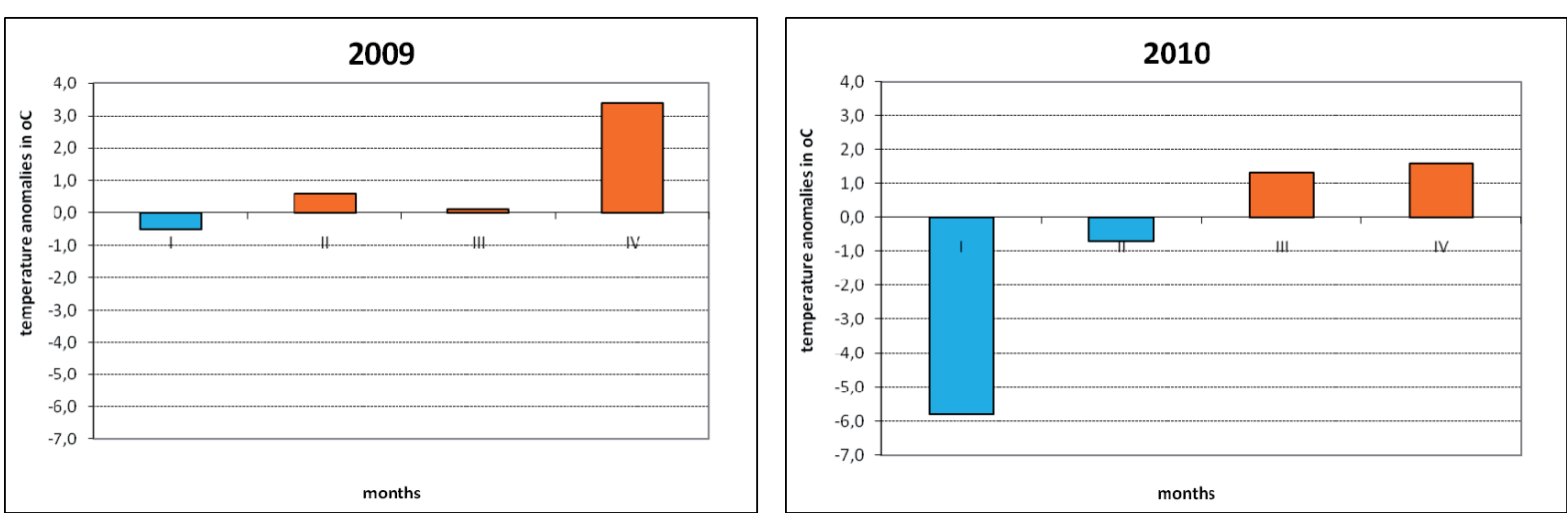

1.

2.
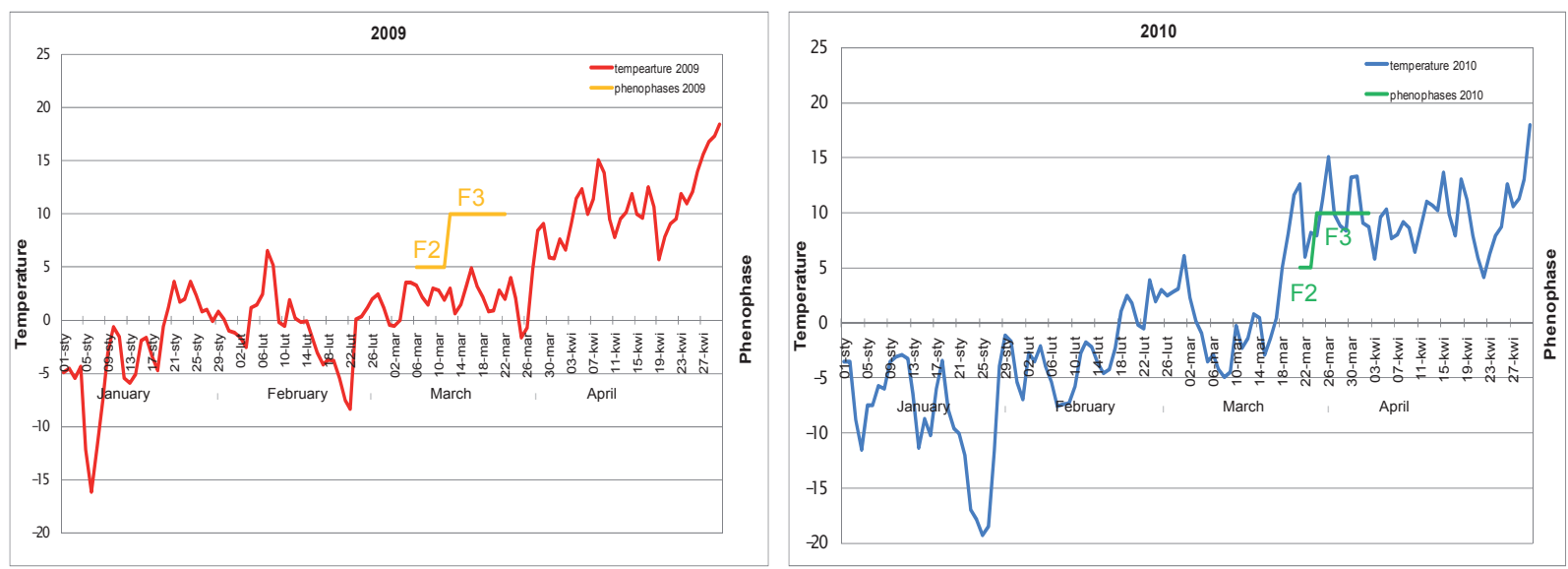

3.

4.
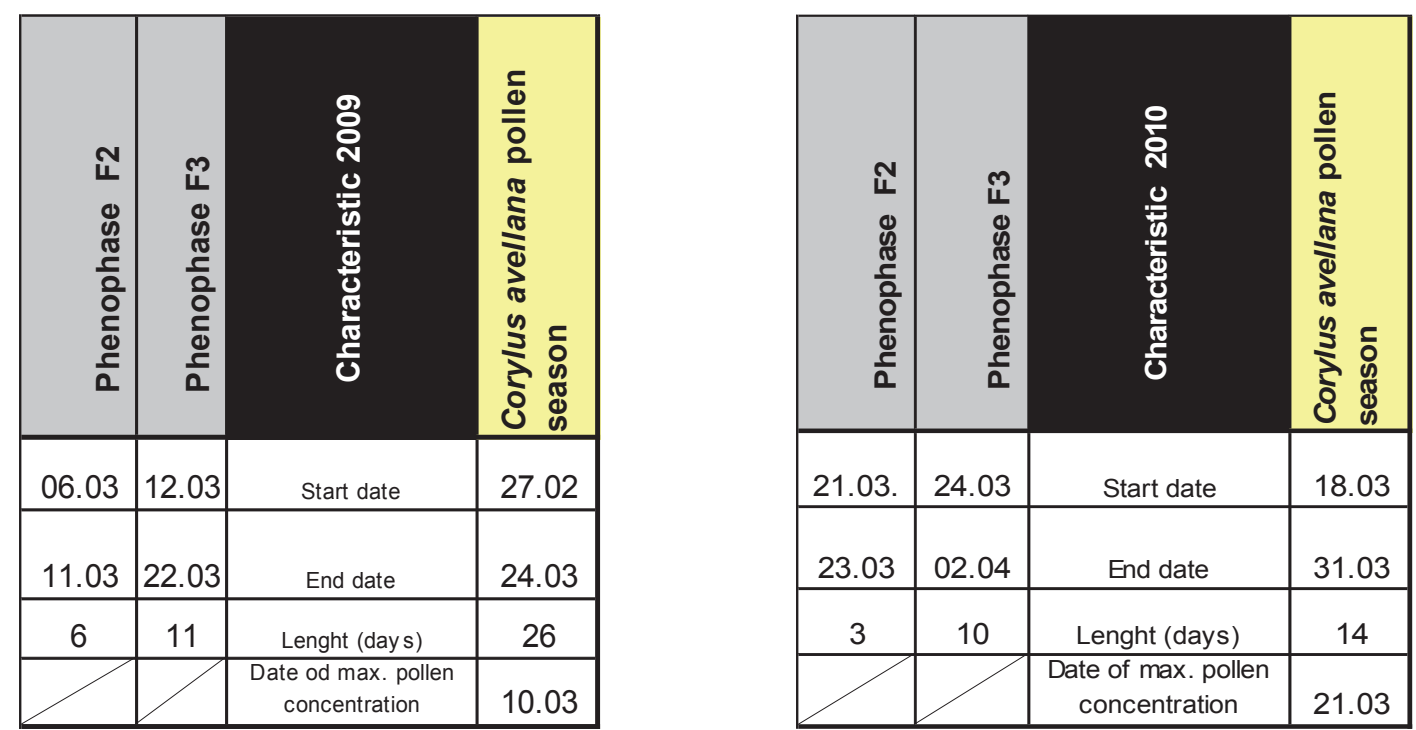

5.

6.

Figs 1 ,2. Monthly mean temperature anomalies in Warsaw in 2009-2010 (reference period 1971-2000)

Figs 3, 4. Daily average temperature and the pattern of hazel phenophases F2 and F3 in Warsaw in 2009-2010

Figs 5, 6. Characteristics of the hazel pollen season and phenophases F2 and F3 in Warsaw in 2009-2010 
February 2009 and lasted till the 24th of March. The maximum pollen concentration (114 grains $\times \mathrm{m}^{-3}$ ) was observed on the 10th of March, during phenophase F2 (Fig. 5).

In 2010 both the onset of flowering and the start of the Corylus avellana pollen season occurred later than in the previous year. This was a result of a quite cool winter that we had in Warsaw and in the rest of Poland in 2010, but it was not a typical date for the beginning of the 21st century. Long-time series of phenological data from the area of Poland have proved that currently hazel flowering occurs in the surroundings of Warsaw in the second decade of March, on average. It is earlier than observed in the 50's (the third decade of March).

In 2010 blossoming of the first flowers (F2) was noted on the 21st of March, 15 days later than in 2009 (Figs 4, 6). In line with the rapid growth of average daily temperature in the second part of March 2010 (March 18), we observed very high dynamics of phenophases F2 and F3. Beginning of full flowering (F3) was observed only 3 days after the first hazel flowers started to bloom (F2).

Similar characteristics appeared in the pattern of the pollen season in 2010. It started 20 days later than in 2009, on 18 March 2010, and during the time when the daily mean temperature started to grow and stabilize above $0^{\circ} \mathrm{C}$ (Figs 4, 6). The rapid development of the 2010 pollen season was another analogy to phenophase F2 in 2010. The maximum pollen concentration (132 grains $\times \mathrm{m}^{-3}$ ) was observed on the 21st of March, 3 days after the start of the pollen season and during F2 phenophase. The length of the pollen season was also short in 2010, as it lasted 14 days.

The analysis of the thermal effect on the phenological stages and the pollen release pattern needed more precise calculation. In case of the analysis of mean monthly and daily average temperature, it is difficult to indicate the exact date on which the temperature would be high enough for the first flowers to blossom (F2). For example, in 2009 there were 2 warmer periods with daily average temperature $>0^{\circ} \mathrm{C}$ - in the end of January and at the beginning of February, but the first flowers appeared only when temperature definitely stabilized its positive values - in the first decade of March. Therefore, we decided to check the number of PDD (Positive Degree Days) which can enable the first flowers to blossom (F2). It turned out that phenophase F2 occurred when PDD exceeded 50 during the study years. The number approached 51 on the 5th of March 2009 and the day after phenophase F2 occurred. In 2010 the limit of PDD> 50 was exceeded later, on 20 March. When the number approached 58, then phenophase F2 appeared the next day.

\section{DISCUSSION}

There are a lot of studies on pollen season characteristics of different plant taxa (Piotrowska, 2008) and on the diversity of pollen seasons in different regions of Poland ( $\mathrm{Li} \mathrm{pi} \mathrm{e} \mathrm{c} \mathrm{et} \mathrm{al.} \mathrm{2009).} \mathrm{The}$ comprehensive analysis of temperature correlations with the phenological stages of flowering, performed during this study on Corylus avellana, was useful for a better interpretation of airborne pollen concentration patterns in the study years.

The use of phenological data from the nationwide phenological database in various interdisciplinary research can lead to interesting results. It can be important especially due to the fact that this phenological database has long time series data, since the 50's, for a major part of Poland. Analyses of the phenological phases of indicator plants for selected seasons have shown that also in our country there are clear tendencies to an earlier start of the plant growing season, in particular in the case of early spring plants (M e n z e 1 et al. 2006). In Poland decreasing trends in Corylus avellana flowering have been estimated at about -2.4 days/decade (J a t c z a k, 2007).

Although the late hazel flowering date in 2010 did not show this tendency, it does not undermine the conclusions of long time series analysis. The interannual variability in flowering dates is only a result of specific meteorological conditions each year.

Unfortunately, there is a lack of such long time series of pollen data, but we can suspect that the hazel pollen season has changed similarly to the time pattern of its flowering. Thus, despite the more common use of phenological data in pollen prediction models, there could also be a considerable potential for studying the dynamics and increases in pollen concentrations and allergy symptoms in Poland. In particular in our country, due to the lack of long time-series pollen data, phenological data and known relationships between phenological stages and the time when plants start to release pollen can be useful.

Because of high sensitivity of plants to weather conditions, it is important to know as precisely as possible the impact of meteorological conditions on plant reactions.

The derived value of PDD $>50$, which caused the first hazel flowers to bloom (phenophase F2) in the study years, requires testing in future years to make the threshold values credible. Similar thermal thresholds can also be set for the time of pollen release.

With the known values of pollen concentration thresholds when allergy symptoms occur ( $R$ a p i e j k o et al. 2004) and thermal thresholds for flowering and pollen release, prevention of allergic diseases may become more effective. 


\section{REFERENCES}

Jatczak K., 2007. Fenologiczna odpowiedź na tendencje zmian klimatu w Polsce na tle zmian zachodzących w Europie. / The phenological response to climate change trends in Poland against the background of changes taking place in Europe. Wiadomości Met. Hydr. Gosp. Wod. 1: 37-48 (in Polish).

Kasprzyk I., Walanus A., 2007. Flowering and airborne pollen - a novel statistical approach. Acta Agrobot. 60 (2): 51-55.

Lipiec A., Malkiewicz M., Chłopek K., Puc M., Myszkowska D., Piotrowska K., Weryszko-Chmielewska E., Zielnik-Jurkiewicz B., Modrzyński M., Dmochowska D., Królikowska G., Jakubowska K., Rapiejko P., 2009. Analiza stężenia pyłku leszczyny w wybranych miastach Polski w 2009 r. / An analysis of hazel pollen concentrations in some cities of Poland in 2009. Alergoprofil, 5 (1): 44-48 (in Polish).

Menzel A., Sparks T., Estrella N., Koch E., Aasa A., Ahas R., Alm-Kübler K., Bissolli P., Braslavská O., Briede A., Chmielewski F., Crepinsek Z., Curnel Y., Dahl A., Defila C., Donnelly A, Filella Y., Jatczak K., Míge F., Mestre A., Nordli Ø., Peñuelas J., Pirinen P., Remišová V., Scheifinger H., Striz M., Susnik A., van Vliet A., Wielgolaski F. E., Zach S., Zust A., 2006. European phenological response to climate change matches the warming pattern. Global Change Biology, 12 (10): 1969-1976.

Naik G., 2007. Global Warming may be spurring allergies, The Wall Street Journal, May 4-6: 9.

Pałczyński C., 2004. Alergia w miejscu pracy - prognozy epidemiologiczne i perspektywy profilaktyki higienicznej. / Allergies at the workplace - epidemiological forecasts and health prevention prospects. Medycyna Pracy, 55 (1): 41-45 (in Polish).

Pidek I. A., 2007. Nine-year record of Alnus pollen deposition in the Roztocze region (SE Poland) with relation to vegetation data. Acta Agrobot. 60 (2): 57-64.

Piotrowska K., 2008. Ecological features of flowers and the amount of pollen released in Corylus avellana (L.) and Alnus glutinosa (L.) Gaertn., Acta Agrobot. 61 (1): 33-39.

P u c M., 2007. The effect of meteorological conditions on hazel (Corylus spp.) and alder (Alnus spp.) pollen concentration in the air of Szczecin. Acta Agrobot. 60 (2): 65-70.

Rapiejko P., Lipiec A., Wojdas A., Jurkiewicz D., 2004. Threshold pollen concentration necessary to evoke allergenic symptoms. Int. Rev. Allergol. Clin. Immunol. 10 (3): 91-94.

Silja mo P., 2007. Development and Application of Biogenic Emission Terms as a Basic of Long-Range Transport of Allergenic Pollen. Air Pollution Modeling and Its Application XIX: 155-162.

St u d e r S., S t ö c k li R., Ap p e n z e 11 e r C., V i d a le P. L., 2007. A comparative study of satellite and groundbased phenology. Int. J. Biometeorol. 5: 405-414.
S z c z e p a n e k K., 1994. Pollen fall in Kraków in 1982-1991. Zeszyty Naukowe UJ, Prace Geograficzne, 97: 9-22.

S z c z e p a n e k K., 2003. Wytwarzanie i rozprzestrzenianie spor i ziaren pyłku. [In:] Palinologia. / Production and dispersal of spores and pollen grains. [In:] S. DybovaJachowicz, A. Sadowska (Eds.) Palynology, Wyd. Inst. Botaniki PAN, Kraków: 16-28 (in Polish).

Walanus A., 1995. Statistical analysis of correlations between pollen rain and the weather, Zeszyty Naukowe UJ, Prace Geograficzne, 97: 33-47.

Weryszko-Chmielewska E., Rapiejko P., 2007. Analysis of Alnus spp. pollen seasons in Lublin and Warszawa (Poland), 2001-2007, Acta Agrobot. 60 (2): 87-97.

\section{Wykorzystanie wyników ogólnopolskiej sieci obserwacji fenologicznych roślin do badania wpływu zmian w fenologii gatunków na stężenie pyłku roślin w powietrzu}

\section{Streszczenie}

Zastosowanie danych fenologicznych w kompleksowych analizach $\mathrm{z}$ danymi meteorologicznymi i aerobiologicznymi umożliwia wnioskowanie na temat zmienności terminu początku pylenia i dynamiki tego procesu w aspekcie oddziaływania czynnika meteorologicznego. Jest to istotne $\mathrm{z}$ uwagi na wyniki badań przeprowadzonych w Europie, które wykazały, że fenologia gatunków wyraźnie reaguje na rosnące trendy temperatury.

Pomimo, że obserwacje fenologiczne nie podlegają standaryzacji a metodyka obserwacji oraz dobór gatunków zależne są od wymogów konkretnej sieci fenologicznej. Znacząca większość danych fenologicznych wskazuje na tendencję wydłużania okresu wegetacyjnego o ok. 2 tygodnie w drugiej połowie XX wieku w średnich i wysokich północnych szerokościach geograficznych, np. w Niemczech przesunięcie terminu wiosennych faz fenologicznych oszacowano na ok. -1,6 dnia na dekadę w Szwajcari: na ok. -2,3 dni na dekadę.

Również w Polsce obserwujemy tendencje do przyspieszania terminu początku procesów rozwojowych roślin. Analizy wieloletnich serii danych fenologicznych wskazują, że kwitnienie leszczyny w latach 50-tych XX wieku występowało w okolicach Warszawy później (średnio: w trzeciej dekadzie marca) niż ma to miejsce na początku XXI-go wieku (średnio: w drugiej dekadzie marca). Pomimo braku tak długich serii danych dotyczących stężenia pyłku roślin można podejrzewać, że zmiany sezonów pyłkowych u tego gatunku zachodziły analogicznie do zmian kwitnienia.

Rośliny wykazują dużą wrażliwość na zmiany warunków pogodowych, dlatego ważne jest, aby moż- 
liwie najdokładniej poznać mechanizm wpływu warunków meteorologicznych na ich procesy fizjologiczne. Ustalenie progów termicznych dla określonej reakcji roślin może być w tym celu korzystne. Oszacowana wartość Positive Degree Days (PDD>50), przy której zaobserwowano zakwitanie pierwszych kwiatów leszczyny (fenofazę F2) w okresie badawczym, wymaga weryfikacji w latach następnych, aby uwiarygodnić poprawność ustalonych progów termicznych. 